\title{
Becoming a Complete Person : Discussing the Aim of Confucian Education
}

\author{
Dr. Wen Ma \\ Langfang Normal University, China
}

\begin{abstract}
The Confucian idea of humanness (Ren) is most commonly translated as "benevolence". The aim of enhancing one's virtue such as benevolence is to perform one's occupation; to position oneself in the world; and to managing the state. Through teaching archery, charioteering(truth), rites(good), and poetry(beauty), the Confucian education aims at cultivate consummate individuals with complete characteristics. The application of Confucian education in the current early childhood education will be discussed.
\end{abstract}

Keywords: will, collaboration, independence, self-system; public good; courage.

\section{GENERAL TRENDS}

The Confucian idea of humanness (Ren) is most commonly translated as "benevolence", and "humanity", occasionally as "human-heartedness". The purpose of enhancing one's virtue such as benevolence is to perform one's occupation; the purpose of connecting with people is to position oneself in the world; and the purpose of managing home is to managing the state (Connolly, 2013). In this article, I will discuss the Confucian education that aims at enlightening truth, approaching good, and pursuing beauty. The application in the current early childhood education will be introduced.

\section{INTELLECTUAL EDUCATION THAT ENLIGHTENS TRUTH}

The Confucian intellectual education emphasizes on mastering the complex techniques of archery and charioteering. For archery, there are five techniques. 白矢 or a white arrow tip refers to the shooter's ability to make the arrow tip's colour turn white when it goes through the target. This skill demonstrates the arrow's rapid speed and the shooter's powerful arm strength. 参连 reefers to the successive shots and the shots will fall on the same point. At first, one arrow is released, then another three. The four releasing shall make perfect aiming. This skill tests the archer's motor/muscle to control the shooting and use of subconscious mind and great concentration. 胱注 describes the look of the arrow while it is flying. The end of the arrow should be higher and the arrow tip should be lower as if it is driving at a certain speed. Good practical accuracy is for hunting or for war. 襄尺 refers to the humble manner of the archer. When the emperor appears, the archer should stay behind the emperor rather than besides him. The fifth technique is called 井仪, which means the archer shall release four arrows at the same time; and the four arrows should make the word 井 at the target. This technique demonstrates the archer's shooting accuracy and eye/hand coordination. Archers with these five skills can normally achieve good practical accuracy for hunting or for war.

The Book of Poetry records the Master archery and his skill:

The Bowstring thimbles and armlets were fitted on;

The bows and arrows were adjusted to one another;

The archers acted in union,

Helping us to rear a pile of game (Book of Poetry, Che Gong: 5) 
This passage shows that teaching archery is not only a physical training, a skill-preparation for war or competition, but it is also a form of practice to identify problems and solve problems.

Five skills are needed for charioteering: sound, controlling, maneuvering, dancing and hunting (Rites of Zhou). Specifically, sound refers to that when the cart is moving, the sound of the bells on the cart shall be in harmony. This skill tests the driver's ability to adjust the rhythm of the cart. Controlling skill is that when the cart is moving in a curving riverbank, the driver must be able to control the cart and maintain its steadiness. In the battlefield, there will be two stones with fly poles placed on them and the driver needs to pass through the narrow space in between the two stones. At this time, a driver must maneuver the cart well so that he can be passing by the barriers carefully and successfully. Dancing skill refers to the driver's ability to drive the cart on crossing roads where carts are coming from all directions. The driver must be able to adjust the angel of the cart like it is dancing in rhythm. Finally, the driver must be able to keep the animals on the left side sot hat he can hunt them (Rites of Zhou, Diguan: Bao Shi Translation is mine). These five techniques illustrate the driver's capability to pay close attention on himself, the horse or the cow, the cart, the road condition, and the tasks. The image of a driver is illustrated in the Book of Poetry"

So did the officers conduct this expedition,

Without any clamour in the noise of it.

Truly a princely man is [the king]

Great indeed are his achievements! (Book of Poetry, Xiao Ya: Che Gong: 8).

Thus, a charioteer combines his mind and heart to perform his duty and holds a sense of purpose and pride.

The specific issue in early childhood education is this: students are not used to the idea of working independently when learning something (Annevirta \& Vauras, 2001). In childcare centre, it is easily observed that children often complain about how difficult the tasks are and how tired they are as soon as a planed-activity begins. Confucius teaches us, one of the important intellectual character is courage (Jiang, 2012). Whether it is life accomplishments or academic performances, nothing can be obtained with ease. To face difficulties, to accept challenges,to welcome uncertainties, and to use full strength to reach the final goal no matter how difficult the circumstances are, they are motivation that courage brings. Courage is not just a physical form of intelligence. As far as physical strength is concerned, cows' or horses' physical strengths are far better than humans. Human courage must include intellectual qualities such as morality and wisdom. Courage always manifests itself at the moment of completing a professional career and during the experience of revealing the truth of life.

According to the Confucian education, an important component of courage is independence. Independence refers doing our own profession and not relying on others. What keep us standing on the ground are our feet. What keeps us positioning in life and making a living is independence. To think with our own mind, to do thins according to our own will, to live with our own capabilities, these are independent things. On the other hand, humans are creatures with feelings. Things we encounter can produce huge impact on us and change our feelings. They make us forget our focus, and give up the duties we have for others, just to meet the immediate need. These distractions are feelings. If feelings emerge and we have no clear mind to carefully judge its contents, we have no control them. In other words, if we merely let feelings to replace mind, we will be in the risk of making mistakes. We cannot blame on feelings for mistakes. The responsibility belongs to those who do not use feelings in the correct way. 


\section{MORAL EDUCATION THAT APPROACHES GOOD}

The most important characteristic that the Confucian education places substantial emphasis on is $L i$, which is often translated as "rite", "propriety", "ceremony" or "manner" (Tan, 2003, 80). The Confucian education teaches students, "if you do not learn the rules of propriety, your character cannot be established" (Analects, Book 16: 13). Rites teaching include "five rites". Ji li (吉礼) is the highest of five ritual ceremonies and worship of the gods, ghosts, ancestors and nature such as mountains, river, forests, fields, rain, etc. Jia li (嘉礼) is the ceremony of wedding and festival activities. It is used to manage interpersonal relationships, communication, or contact the feelings of the etiquette. Bin li (宾礼) demonstrates the implication for moving together with the retainer, hospitality to the princes and dukes of the Quarter to send envoys to the king of Zhou ceremony. Jun li (军礼) is the military drills, the conquest of the Code of Conduct in warfare. And finally, Xong li ( $凶$ 礼) is a variety of unfortunate events, doing mourning, sympathy courtesy ceremony (The Book of Ceremonial Rites -translation is mine). These refined cultural practices direct sage-kings and exemplary persons' good conducts. Consequently, when individuals habitually perform disciplined, graceful and deferential physical postures and movements, they develop reverential, dignified, and modest intentions toward others. In other words, these intentional qualities constitute the moral substance of the embodied and ritualized cultural forms. They are the good exemplifications of the human relations (Lai, 2007; \& Tan, 2003).

Researchers are facing one specific issue in children's moral development. Self-system (Larkin, 2006, p. 8) and its correspondence with the development of self-regulated learning. Selfsystem can be understood as "how membership of a group collaborating towards a single goal can impact on students' morality" (p. 8) .Yet, children are not often given the opportunity to work collaboratively. The emphasis is on individual achievement and individual progress. When the Confucian ethical education talking about the importance of filial piety toward parents, what it tells us is that without our parents, we do not have our bodies; thus, children's responsibility to look after their parents is a natural thing. People in other relationships such as brothers, husband and wife, or friends also have their duties depending on the social roles they have to play. Children at early childhood shall listen to other adults and other peers in terms of developing good social habits such as containing food consumption, maintaining personal hygiene, exercising regularly, sustaining good sleep, and being positive. As far as our personal health is concerned, if we can think from the social perspective, self-care becomes a form of duty. It is wrong to ignore the goodness of others and claim: "I take full responsibility of my unhealthy and weak body and it has nothing to do with others".

The basic standard for moral and ethics are not about things that are far and high. They exist in words and deeds that are close to us such as communicating with others such as with parents, teachers and peers. Self-regulation means to subjugate things we desire to do. If we do not apply intelligence from reasoning and strong will to regulate, moral defects from our wants are obvious. For example, we need to be clear about the fact that friendship belongs to personal morality whereas nation's responsibility concerns public morality. When conflicts occur among the two, we should always obey public morality. The same thing can also happen to the whole country and to all citizens. If we become slaves of our own desires, then the reform of political system, the progress of arts and sciences will not be hopeful for us. The civilization of the nation will also be in danger. This is the reason to commit self-regulated behaviour and good citizenship.

\section{AESTHETIC EDUCATION THAT PURSUES BEAUTY}

The Confucian aesthetic education consists of poetry. Poetry has melody. They are the same as songs. Poetry is taught through the Book of Poetry or Odes (Lai, 2007, p. 48). It comprises 
approximately three hundred poems and is categorized as three types of songs: airs of the states (风), royal songs (雅), praise songs (颂) (Book of Poetry). Airs of the states are a type of folk songs collected from various regions. Royal songs are the formal songs coming from the territories directly managed by the Zhou dynasty. And praise songs consist of dancing music and songs for the purpose of ceremonies to worship gods, ghosts and sage-rulers (Book of Rites, Record of Music; 47). The Confucian education demonstrates the four purposes of learning poetry: "Reciting the Songs can arouse your sensibilities, strengthen your powers of observation, enhance your ability to get on with others, and sharpen your critical skills" (Analects, Book 17:9). We can see from this passage that the purpose of learning Odes doe snot stop at the stage of memorizing poetry. More importantly, students shall connect with the feeling of poetry and understand its meanings so that one can listen to different views, see different things and be adaptive in complex situations while expressing one's wishes and desires (Cai, 1999). In other words, a poetic character is vital for an exemplary person; and the teaching of the Odes aims for "mild and gentle, sincere and good" personality (Book of Rites: The different teaching of the different kings: 1 ).

The main issue in early childhood education is this: researchers are concerned about young children's self-awareness. Self-awareness is to know oneself and how one's individual characteristics influence one's behaviour. It is commonly believed that children have a pervasive lack of awareness of their mental activity. Children's "mental activity" includes their cognitive knowledge and cognitive regulation (Flavell, 1987). Cognitive knowledge refers to the individual's knowledge about personal strength, weakness. Cognitive regulation reflects the requisite awareness to choose when faced with negative situations (Davis, et al, 2010, p. 507). The consequence of children with less proficient self-awareness exhibits behavioural problems including difficulty with peer relationships and school adjustment (Jacobs, 2004). For example, when I was observing in a childcare centre, I was writing down what I noticed on a notebook. A your-year-old girl approached me and asked "What are you doing?" When I told her that "I was doing homework". She immediately questioned: "Does doing homework get paid?" Another instance occurred at the centre's kindergarten class. The teacher asked the whole class, "are you happy?" A five-year-old boy raised his hand and stood up: "I am not happy". He answered. "Why?"The teacher asked: "Because I am poor, I do not have any money"!

In today's world, humankind's material needs has been greatly met as a result of impressive development of progressive of science and technology. Nevertheless, material abundance has caused the great loose of human control such as massive social consumption, unlimited-taking, and narrow-mindedness. For the Confucian ideals, education that is missing the component of aestheticity is the ignorance of aesthetic education. In order to bring the abstract beauty to concrete reality, beauty has to be immersed in everyone's feeling and will, and convert itself to become a sense of agency for one's conduct. To reasonably use feelings, we need rationality to regulate them just like we use a delicate switch to channel the power of steam from a steam machine. We have to control feelings. What are the specific self-control strategies? To be flexible when encountering unforeseen life circumstances rather than holding unpleasant emotions, to have appropriate level of joy rather than having limitless wanting, to listen to classical music to calm down our feelings; to recite or even write poem to express ourselves; when we are sad, we can climb mountains to relax. Then when we try to remember the angry feeling and said attitude, we realize that anger and sadness are unnecessary. When are accomplish these things, we can be called an independent and mature person. 


\section{CONCLUSION}

As far as I am concerned, the above elements of the Confucian education lead to cultivating one's inner quality of exemplary person. In other words, to know who one should be and what one should do. When one of the most talented disciples Yanyuan asks about the nature of selfcultivation, "The Master replied: through self-discipline and observing ritual propriety ( $L i$ ) one becomes authoritative in one's conduct. If for the space of a day one were able to accomplish this, the whole empire would defer to this authoritative model (Analects, Book $12: 1$ )

Self-interest is the strongest factor that is likely to distort an individuals' judgement and deflect him or her from one's moral purpose. Confucius reminds us that at the sight of profit one should think of what is right and whether one's conduct reflects one's nature as "comsummate" (Book 14:2). He warns people in young, middle and old age against self-centered wishes (Book 16:7).

A Confucian virtuous person is able to overcome the self and love and care for others and consider this attitude as the ultimate life purpose (Hall, 1998). Through education that enlightens truth, approaches good and pursues beauty, an individual will be able to achieving the aim of becoming an "consummate" person - a complete individual consists of characteristics of truth, good, and beauty!

\section{BIBLIOGRAPHIES}

Ames, R. T., \& Rosemont, H, Jr. (1998). The Analects of Confucius: A philosophical translation. The Ballantine Publishing Group: New York.

. Book 1: 1, 2.

Book 12:1.

Book 14: 2.

Book 16: 7, 13.

Book 17: 9.

Annevirta, T. \& Vauras, M. (2001). Metacognitive knowledge in primary grades: A longitudinal study. European Journal of Psychology of Education, XVI (2), 257-282.

Cai, Z. (1999). In quest of harmony: Plato and Confucius on Poetry. Philosophy East and West, 49(3), 317-345.

Connolly, T. (2013). Introduction: teachers, friends, and truth. Journal of Chinese Philosophy, 40(S), 8-11.

Citations of the Confucian works are to be critical edition published by Chinese Text Project. Chapter and passage numbers follows the book titles.

Legge, J. (trans.). Book of Poetry. Retrieved from http://etext.org/ancient-classics.

. Che Gong: 5. 8. In Legge, J. (trans.), Book of Rites.

http://etext.org/ancient-classicis.

. Book of Rites. Retrieved from http://etext.org/liji.

. The meaning of the ceremony of archery: 4.5.7. In Legge, J. (trans.), Book of Rites.

Http://etext.org/liji.

. Record of Music: 1, 6, 16, 47. In Legge, J. (trans.), Book of Rites . http://etext.org/liji.

. The Different teaching of the different kings: 1, 2, 5, 6. In Legge, J. (trans.), Book of Rites.

http://etext.org/liji.

The Book of Ceremonial Rites. (2014, Janurary- May). Retrieved from http://etext.org.yili.

Davis, E. L., Levine, L. J., Lench, H. C., \& Quas, J. A. (2010). Metacognitive emotion regulation: Children's awareness that changing thoughts and goals can alleviate negative emotions. Emotion, 10(4), 498-510.

Fang, Z, \& Cox, B. E. (1999). Emergent metacognition: A study of preschoolers' literate behaviour. Journal of Research in Childhood Education, 13(2), 175-187. 
Flavell, J. H. (1987). Speculations about the nature and development of megacognition. In F. E. Weinert \& R. H. Kluwe (Eds.), Metacognition, motivation and understanding (pp. 21-29). Hillsdale, New York: Erlbaum.

Hall, D., \& Ames, R. (1998). Thinking from the Han: Self, truth, and transcendence in Chinese and Western culture. Albany: State University of New York Press.

Jacobs, G. M. (2004). A classroom investigation of the growth of metacognitve awareness in Kindergarten children through the writing process. Early Childhood Education Journal, 32(1), 17-23.

Jiang, X. (2012). Confucius' view of courage. Journal of Chinese Philosophy, 39(1), 44-59.

Lai, K. L. (2007). Understanding change: The interdependent self in its environment. Journal of Chinese Philosophy, 34(1), 81-99.

Larkin, S. (2006). Collaborative group work and individual development of metacognition in the early years. Research in Science Education. 36, 7-27.

Rogoff, B. (2003). The cultural nature of human development. New York; Oxford: Oxford University Press.

Perry, N. E., VandeKamp, L. O., Mercer, L. K., \& Nordby, C. J. (2002). Investigating teacher-student interactions that foster self-regulated learning. Educational Psychology, 37(1), 5-15.

Tan, S. (2003). Confucian democray: A Deweyan reconstruction. Albany, NY: State University of New York Press. 